\title{
An Orchestra Faces the Test of Indeterminacy
}

John Tilbury and the Sans Project

L'orchestre à l'épreuve de l'indétermination. Une ethnographie du projet Sans

\section{Clément Canonne and Alexandre Robert}

Translator. Daniela Ginsburg

\section{OpenEdition \\ Journals}

Electronic version

URL: https://journals.openedition.org/bssg/643

DOI: $10.4000 /$ bssg. 643

ISSN: 2490-9424

Publisher

Presses universitaires de Vincennes

Electronic reference

Clément Canonne and Alexandre Robert, "An Orchestra Faces the Test of Indeterminacy", Biens

Symboliques / Symbolic Goods [Online], 8| 2021, Online since 20 May 2020, connection on 23 July 2021. URL: http://journals.openedition.org/bssg/643 ; DOI: https://doi.org/10.4000/bssg.643

This text was automatically generated on 23 July 2021.

Biens Symboliques / Symbolic Goods 


\section{An Orchestra Faces the Test of Indeterminacy}

John Tilbury and the Sans Project

L'orchestre à l'épreuve de l'indétermination. Une ethnographie du projet Sans

Clément Canonne and Alexandre Robert

Translation : Daniela Ginsburg

1 Orchestras have been important objects of study within the sociology of music. In a critical vein, driven by the work of Adorno (1976), they have been seen as sorts of social microcosms, revealing society's antagonisms and contradictions (Willener 1997). On account of the diversity of their members' musical and social trajectories, they have also given rise to analyses pointing to the various capitals, dispositions, and interests that instrumentalists bring to the practice of their profession (Lehmann 2005). And finally, orchestras have been particularly fertile sites for sociology to study the collective and interactive dynamics at work in artistic creation (Faulkner 1973; François 2002; Ravet 2015).

2 If orchestras have been such objects of fascination, it is no doubt because they directly raise the question of musical production by a large ensemble: how do such big, diverse groups succeed in making music together? This question has generally been raised within the "traditional" framework of the symphony orchestra, a framework based on a very precise internal mode of operation (a clear division of roles, pyramidal organization, etc.) and a highly normative and prescriptive repertoire. But can an orchestra function without these two resources? And if so, how? 
Fig.1.

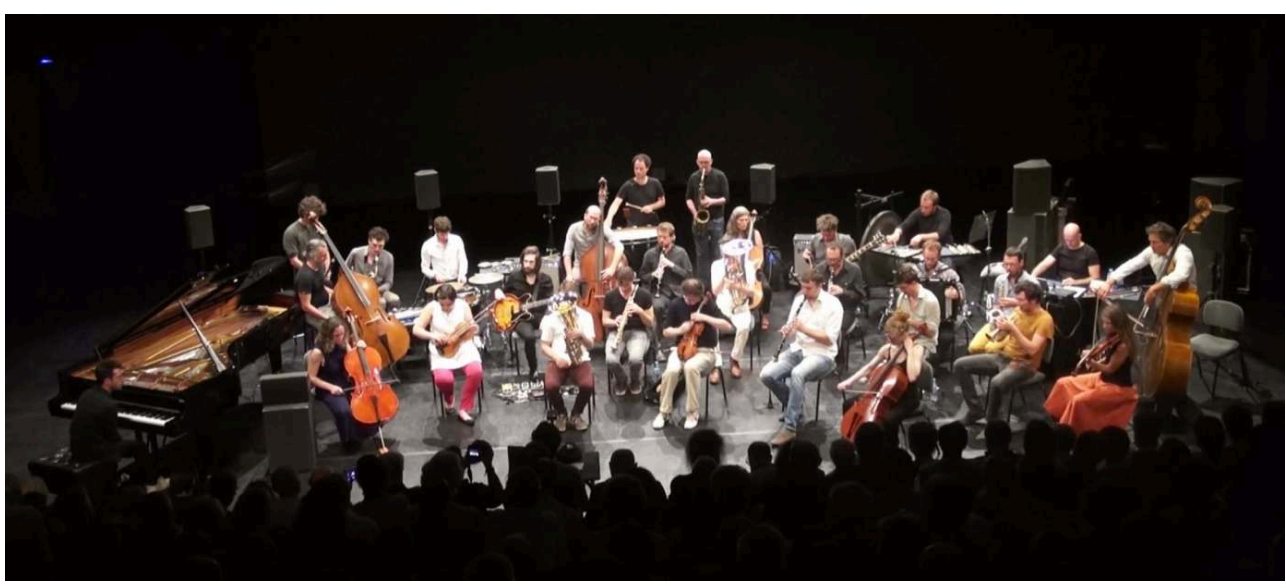

The ONCEIM during the performance of Sans, Festival Météo, Mulhouse, 26 August 2017

Source: Clément Canonne

In this respect, the Orchestre des Nouvelles Créations, Expérimentations, et Improvisations Musicales (ONCEIM), constitutes a remarkable limit case. Created in 2011 by the pianist Frédéric Blondy and made up of some thirty instrumentalists with various musical backgrounds (jazz, improvised music, classical and contemporary music, noise music, music informatics, etc.), its artistic activities are based both on large-ensemble "free improvisations" 1 and on commissions from various composersworks that typically combine a written score with improvised material. In both cases, ONCEIM performances are characterized by a high level of indeterminacy, which calls for modes of organizing and working that are unusual for large instrumental ensembles (i.e. a relatively fluid distribution of roles, an emphasis on a "work-in-progress" approach, etc.), resulting in a tension that structures all of ONCEIM's activities.

Such tension was particularly prominent in the project we study in this article. The orchestra's commission of a piece from the pianist and improviser John Tilbury for the Météo Festival ${ }^{2}$ in Mulhouse in August 2017 gave rise to a unique and particular collaboration: although Tilbury provided, in the form of an email, the outline of a verbal score describing part of the performance of his piece Sans, he ultimately refused his role as composer-prescriber throughout the rehearsal process, instead referring the orchestra's players to their "responsibilities" and encouraging them to make certain decisions themselves.

5 What does playing indeterminate music as a large group entail? What organizational, musical, or interactional resources do musicians draw on to meet this challenge? Analysing the collaborative project between ONCEIM and John Tilbury provides elements to answer these questions by shedding light on the effects indeterminacy has on the organization of the collective and on the postures of the individuals that make it up. In the first section, we will focus on the ambiguous status of the project, which oscillated between two regulating ideas of musical activity; next we will analyse the effects that the "power vacuum" created by John Tilbury's non-prescriptive stance had on the orchestra; and finally, we will show how the project's indeterminacy served to reveal the various relations to musical performance that coexist within the orchestra.

Fieldwork 
Our analysis is based on two types of data. First, one of the co-authors carried out an ethnographic study, including video documentation, of all the rehearsals held by John Tilbury and ONCEIM in Paris and in Mulhouse (22-25 August 2017) and conducted an interview with Tilbury after the dress rehearsal (25 August 2017). In so doing, he was able to draw on his prior familiarity with the practice of free improvisation and with certain members of ONCEIM; this relationship of proximity to the object of study greatly facilitated access to and immersion in the heart of the work process. Second, the other co-author carried out a series of semi-directed interviews in which video extracts from the rehearsals were used to recreate individual scenarios and musicians' artistic trajectories were discussed. These interviews were carried out between January and February of 2018 with 9 ONCEIM musicians (one woman and eight men $^{3}$ ): two bassists, one cellist, three clarinettists, two saxophonists, and one trumpeter ${ }^{4}$ ). The second co-author's lesser familiarity with the field and with the Tilbury project led interviewees to offer explanations and verbalisations of certain aspects of their experiences that proved fruitful for our analysis.

\section{Sans, a Project of Ambiguous Status}

Before delving into the collaboration itself, it is useful to focus on several objective properties of ONCEIM that will help us adequately frame the work context shared by the orchestra and John Tilbury.

7 ONCEIM is clearly located at the cultivated, legitimate pole of the space of musical production: it focuses on exploring a repertoire that ranges from large-ensemble free improvisations to new works of "contemporary music" for orchestras. Its members, most of whom trained in a conservatory (primarily the prestigious, highly selective Conservatoire National Supérieur de Musique de Paris), share the same "aesthetic" relation (Bourdieu 1984: 28-29) to music and sounds, as well as various avant-garde values such as innovation and experimentation ${ }^{5}$.

In contrast to traditional symphonic orchestras, ONCEIM's composition is characterized not by the functional complementarity of sections (strings, woodwinds, brass, and percussions) but rather by the aesthetic complementarity of "individualities." While there is significant instrumental diversity (thirty-two musicians playing seventeen different instruments), members have been recruited in such a way as to ensure a variety of musical profiles (they have backgrounds in free improvisation, free jazz, electronic music, contemporary music, etc.) and instrumental "sensibilities'." Thus, in contrast to a "traditional" orchestra, where the homogeneity of musicians' experiences and training is complemented by a collective practice that is significantly different for each section, ONCEIM brings together artists with unique experiences and backgrounds to participate in a potentially homogenising collective practice -the quest for a shared mode of operating that de facto allows musicians to improvise together as an orchestra.

Although, in ONCEIM, group discussions and musical performances are based in part on an egalitarian ideal that is particular to the practice of improvised music (Becker 2000), the organization of its work does not exclude all forms of hierarchy. On the one hand, responsibility for artistic programming is entrusted to an artistic committee (elected for a two-year period) made up of several members of the orchestra. And on the other, 
ONCEIM's founder and artistic director, Frédéric Blondy, holds a very particular position: he serves both as an outside ear who can give musicians critical feedback by providing an overall perspective on the music produced by the orchestra (thus going beyond the sum of subjective impressions felt from "within") and as the organizer of the group's work, whether this means determining the content of rehearsal sessions (proposing exercises, etc.), deciding on practical details (how long breaks will be, etc.), or maintaining harmony between musicians who sometimes have very different aesthetic preferences.

10 Thus, a certain organizational ambiguity runs through ONCEIM's operation, which adopts either a "horizontal" model of relations or a "vertical" one to varying degrees depending on the project. This ambiguity is reinforced by musicians' diverse working habits, which are closely connected to their career paths and prior socializations-a point to which we will return in the third section.

11 This mixture of organizational modes as well as of practices of creation could be seen (and heard) particularly clearly in the collaborative project that brought ONCEIM and John Tilbury together. As we have noted, the idea of commissioning a piece from Tilbury fits perfectly within the parameters of ONCEIM's institutional and artistic operations. However, it represented a first for Tilbury, who is internationally recognized as a performer ${ }^{7}$ and improviser ${ }^{8}$, but had never before tried his hand at composing. In light of this, it is hardly surprising that he did not present ONCEIM with a conventional score prescribing to each musician the sounds and instrumental actions he or she should perform. Instead, shortly before work sessions with the orchestra began, Tilbury sent the ONCEIM musicians the e-mail reproduced below, in which he presented his project: 
Fig. 2.

Our performance of Sans, circumstances have obliged us to make certain
s to the original plan. The text will be recorded in Paris on Tuesday, 22 August.

In performance this recorded version will be used. It will not be delivered 'live',

The recording will begin with string players, then woodwind and saxophones, brass, piano.

E.G.

Par. 1 Patricia

2. Cyprien,

3. Elodie,

4. Felicie

5. Anais

6. Deborah

7. Xavier

ETC. I have chosen a short text by Samuel Beckett. Sans (in the original French), because I think
Beckett's intellectual and moral toughness will serve us well.

There are 29 performers, which is 5 more than we need. I am thinking of a short instrumental We will decide on this when we meet up in Paris:

The text should be read with a quiet intensity, and with clarity - no dramatisation.

In this first part the text is primary and the music is not secondary. The text itself is not the sole
source of meaning.

After each paragraph there will be a pause before the next paragraph ; the longer the paragraph
(eg 17) the longer the following pause, but not too long. The continuity should be maintained.

In performance : after a player has completed her paragraph she will begin to play her instrument and will continue playing untit the complete text has been performed, playing continually, but make sure, by playing softly, or not at all, that the text is clearly audible.

The music : re the music. I should like the text to be the determining factor. I would prefer the reflective, accompanimental, questioning, It is self-sustaining and private, of a 'avet intensily'

The text, both French and English versions, consists of 24 Paragraphs, and a total of 120 sentences. Each sentence occurs twice, once in each half (there are 60 different sentences), e.g.

Extract from John Tilbury's email to the musicians of the ONCEIM, 19 August 2017

Source: ONCEIM 
Fig. 3.

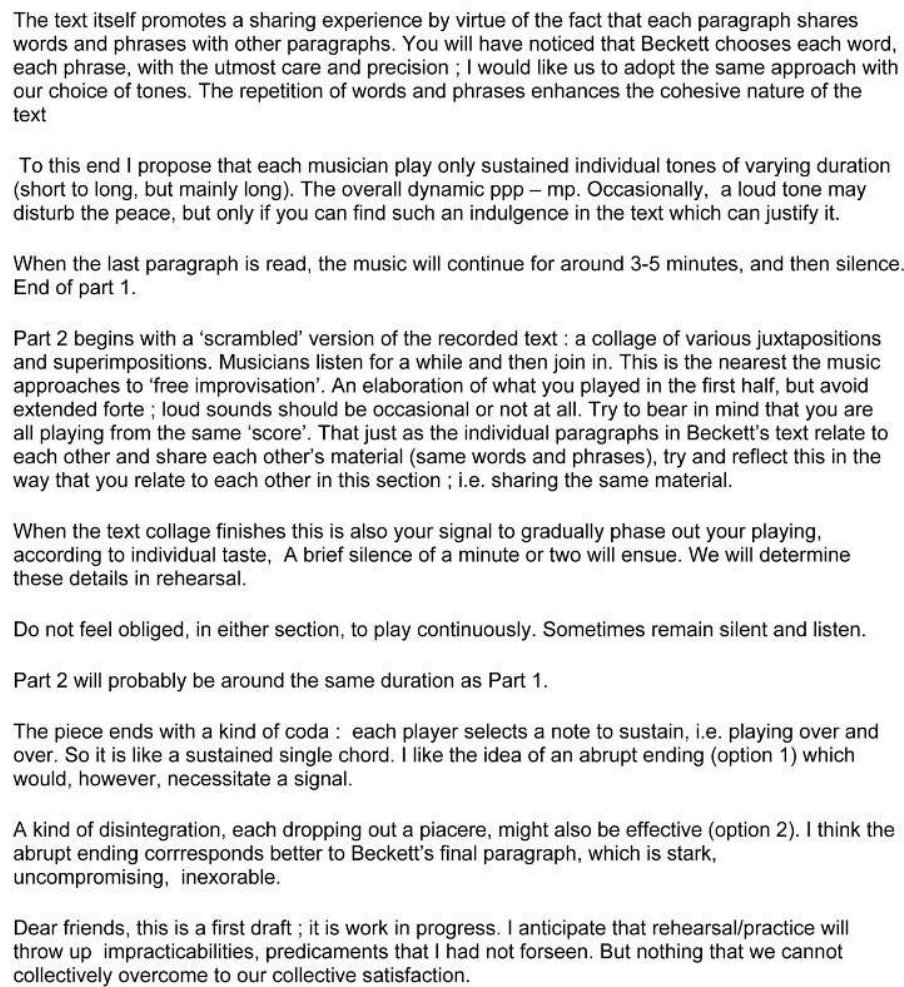

The piece ends with a kind of coda : each player selects a note to sustain, i.e. playing over and over. So it is like a sustained single chord. I like the idea of an abrupt ending (option 1) which would, however, necessitate a signal.

A kind of disintegration, each dropping out a piacere, might also be effective (option 2). I think the abrupt ending corrresponds better to Beckett's final paragraph, which is stark,

uncompromising, inexorable.

Dear friends, this is a first draft ; it is work in progress. I anticipate that rehearsal/practice will throw up impracticabilities, predicaments that I had not forseen. But nothing that we cannot collectively overcome to our collective satisfaction.

Extract from John Tilbury's email to the musicians of the ONCEIM, 19 August 2017

Source: ONCEIM

12 When ONCEIM and Tilbury began their work together, a part of this text was translated into French, printed, and distributed to the musicians, serving as the "beginning of a score" (to use Frédéric Blondy's words). Several days later, the ONCEIM musicians gave a nearly one-hour performance at the Mulhouse Météo Festival, an extract of which can be seen here:

This media file cannot be displayed. Please refer to the online document http:// journals.openedition.org/bssg/643

How did such a short email give rise to the constructed, organic performance the audience heard at Mulhouse? Answering this question requires zooming in on the process of collaboration between John Tilbury and ONCEIM.

We must begin by recalling that the project belongs to the tradition of so-called "indeterminate" music, a tradition that includes the graphic scores for Treatise (1963-1967) by Cornelius Cardew and the verbal scores Christian Wolff brought together in Prose Collection (1969-1985), and to which Tilbury has dedicated most of his work as a performer ${ }^{9}$. Indeed, Sans belongs to the tradition of indeterminate music on two counts: first, it proposes a framework full of vague, suggestive, and even quasicontradictory statements, which leaves musicians with a great deal of interpretive latitude, and second, it explicitly calls into question the usual division of roles between the composer-author on the one hand and the interpreters-performers on the other:

"It's not my music, it's their music. So I've created a situation where we come together ... and obviously, without my input, without the input of Beckett, the 
music would be different ... so we are a large determining factor, Beckett and me, in what and how the orchestra is playing. But whether it's my piece, I would hesitate to say that" (interview with John Tilbury).

But the ambiguity-of both scripts and positions-inherent to this kind of indeterminate musical project was accentuated in the interactions between Tilbury and the ONCEIM musicians during rehearsals.

First, the context of the project created a certain expectation on the part of musicians: that Tilbury would take on the role of composer and/or artistic director in leading the work-that is, that he would position himself as the prescriber of the musical actions to be carried out. On account of his participation in AMM (Saladin 2014), Tilbury has considerable symbolic capital within the space of free improvisation; thus, the musicians were disposed to give a certain weight to the remarks he made over the course of rehearsals ${ }^{10}$. This authority effect was strengthened by the fact that he chose to put a text by Samuel Beckett at the centre of the project. In addition to the prestige the musicians associated with the figure of Beckett as a result of the kind of cultural capital they themselves possessed, we must also emphasize here the particular relationship between Tilbury and Beckett, a relation to which Tilbury referred several times during rehearsals by recounting personal anecdotes about Beckett or discussing his artistic or philosophical positions.

8 Next, the project existed within the framework of a commission: ONCEIM, via its artistic committee, asked Tilbury to propose a project for them in view of their creative residency at the Mulhouse Météo Festival-thus placing him in a position of de facto authority, as the festival's program unambiguously demonstrated by listing him as the author of Sans. Thus, at the moment work on the piece began, it was implicitly understood that the musicians were there to serve Tilbury's project.

Finally, the way Frédéric Blondy presented John Tilbury's initial letter to the musicians at the first work session no doubt strongly reinforced its prescriptive aspect, both by instituting the letter as "the beginning of a score" (with the authoritative charge implied by the term "score") and by ignoring the letter's vague, poetic, or suggestive elements and focusing instead on the explicit musical instructions it contained:

"The sounds that you will play will essentially be continuous sounds, to be played with pauses [...]. It is very important throughout the entire first part to remember that we are accompanying the text, so we must always be able to hear the text. [...] John would like a decision to be made before you even begin to play a sound, and each time you play that sound again, you can perhaps vary it, but in such a way that one can recognize a link to the first decision, the first sound that was chosen. We are not radically changing musical material in the first part [...]" (Frédéric Blondy, rehearsal on 22/08/17).

But despite this general framework, which de facto put the ONCEIM musicians in the position of performers and John Tilbury in a position of compositional authority, the latter continued to give multiple indications of his refusal to fully occupy this position. of course, it is common for a composer attending to the rehearsals of the musicians from whom he has received a commission to mostly remain in the background, only intervening at a few key moments or when explicitly invited to do so. There are two main reasons for this. On the one hand, within the tradition of Western classical music since the nineteenth century, a score is understood to stand in for a composer (see Cook 2018: 66-67): on this understanding, ideally, it encodes the composer's musical intentions so clearly that performers do not require any further interaction with him 
or her. On the other hand, the separation of roles between the composer and performers is mirrored by a division of skills and know-how: the composer creates the score, while the musicians (and possibly their conductor) "bring it to life" (Payne 2016). In other words, a composer who intervenes too much is at risk of being seen by the performers to be meddling in their own area of expertise, and in this way robbing them of a significant part of their creative autonomy (Donin 2018).

While there is thus nothing exceptional about a composer taking a hands-off approach in the context of a collaboration mediated by a score, it is not so self-evident in the context of the collaborative framework outlined by Tilbury in his email, which in many respects was more like a programmatic note of intention than a score that could stand in for the composer's concrete presence. And yet, Tilbury endorsed a highly noninterventionist position throughout all the work sessions through various discursive strategies: he stated that he was a novice at composing ${ }^{11}$, he prioritized the musicians' preferences over his own $^{12}$, he shared authorship ${ }^{13}$, he publicly expressed his uncertainties ${ }^{14}$, he explicitly refused to prescribe to the musicians what they must do ${ }^{15}$, he phrased his comments as advice ${ }^{16}$ or possible options ${ }^{17}$, he included himself alongside the musicians ${ }^{18}$, and so on. In other words, far from making the vague parts of the initial "score" any clearer, Tilbury's oral interventions contributed to reinforcing the indeterminate nature of the project.

More generally, placing Beckett's text at the centre of the project also functioned as a form of delegation of authority, allowing Tilbury to position Beckett as an implicit author of the piece-especially because the musicians' interventions were supposed to be primarily determined by Beckett's text (at least in the first part of the piece)-and to focus the bulk of his comments on the question of the audibility of the text and the dynamic equilibrium between the voices played through the speakers and the sounds made by the orchestra, rather than on the individual musical and instrumental choices made by the members of ONCEIM. In many respects, Tilbury took the position of an outside listener coming in to help fine-tune the performance (for example, by discussing the balance between the various instrumental parts, etc.), rather than that of a composer in charge of developing it.

If Tilbury handled prescriptive statements with such caution, this was not merely because of a lack of familiarity with the position of composer; it was also, and above all, out of a "psychological" understanding of the particular context in which the ONCEIM musicians found themselves. Indeed, according to Tilbury's view of the situation, the musicians' connection to the process of creation risked being blocked by overly directive or intrusive interventions, which might contradict their own preferences. His vague instructions were intended to encourage the musicians to take responsibility and make their own contributions. Thus, for the author of Sans, the most important thing in rehearsing with ONCEIM was knowing when to say nothing:

"You have to give the right input, that's very important, that's very complex in a way, psychologically: what not to say and what to say ... but especially: what not to say. [Is] there any point in asking or proposing this? Sometimes there [is], sometimes not. But I tended to consider: 'can I move the project forward by saying this?' Not quite in those words, but it was in the back of my head: to say the right thing, psychologically as well as musically" (interview with John Tilbury). process to the type of relationship Tilbury hoped to have with musicians, was defined 
by a tension between two ways of envisioning the work of creation-a tension perfectly captured by one ONCEIM member:

"On the one hand, he doesn't give us any clear instruction; he says, 'do what you feel, what you want, what you can, you know what you have to do, you are musicians and improvisers too for the most part, so make music' (laughs); and on the other hand, in fact, [there is] his letter, his instructions, his presence, his relationship to Beckett, etc., etc., his aura (laughs), his position as a composer and so, in a way, as an authority nonetheless" (interview with Bertrand, saxophonist, 55 years old).

We must now try to understand how the orchestra's musicians negotiated this paradoxical injunction. How did they proceed in deciding how to perform Tilbury's piece, even as he, concerned as he was that they take ownership and be spontaneous, was focused on not telling them what to do?

\section{2. "Power Vacuum" and Prescriptive Impulses}

From Tilbury's initial email onward, the Sans project was presented as a work in progress that would be developed (or at least made more precise) over the course of the rehearsal process. For many musicians, it seemed therefore clear that prescriptive operations would take place during rehearsals. But, as we have seen, this was not at all the case, which led to a reconfiguration of power relations between project participants during rehearsals: beyond Tilbury's resolutely non-prescriptive stance, the process of working on Sans was peppered with "prescriptive outbursts" from musicians themselves.

We have already mentioned that ONCEIM's artistic director Frédéric Blondy "transformed" Tilbury's letter into a musical score at the very beginning of the rehearsal process by focusing on the elements of the letter that came closest to musical or instrumental instructions. But other moments also demonstrated a desire to define certain aspects of the performance more precisely or to come to an agreement regarding individual or collective ways of arriving at a given result, in the face of Tilbury's refusal to give musicians detailed feedback that would modify their way of playing or to intervene beyond matters having to do with balancing the music with the audio track.

Thus, one of the bassists raised the following question (in English) about the overall execution of the first part of the piece to Tilbury after the musicians had already played it four times:

Sébastien (bassist, 39 years old): "I have a question, about the fact that there is naturally a densification of the music, according to the fact that we are more players at the end of the piece. Is it that you would like the piece to be sort of a crescendo or is it more that you want to have a more various orchestration throughout the piece?"

John: "Yes, the second, really. I don't really want to hear ... have a crescendo [...]. If we think that it is getting a bit loud in relation to the voices, especially towards the end, what you can do is stop playing ... spontaneously... But [we] don't have to have a discussion about it, you're musicians, you know what to do" (rehearsal on 24/08/17).

This response, reminding each player of his or her responsibility as a musicianimproviser, opened up a discussion during which several members of the orchestra expressed their points of view on the general direction of the first movement, with 
some advancing solutions for avoiding the problem of the orchestral crescendo and others pointing out the behaviours that, according to them, were creating this impression of an orchestral crescendo: for example, the tendency of each player to build, throughout the movement, on the material with which he or she had begun; a lack of musical precision that cluttered the orchestral texture; or the fact that the dynamics at the beginning of the piece were far too soft. It is striking to note that most of these interventions were made in the form of prescriptions ("it is necessary to," "we have to") or prohibitions ("there is a threshold that must not be crossed") seeking to affect individual behaviours, whereas Tilbury's interventions were, in general, made as simple suggestions, and always extremely cautiously.

Perhaps even more significantly, Frédéric Blondy took charge of the orchestra in a striking manner in the second part of the piece. In this part, the musicians were supposed to improvise "freely" over an audio track that randomly superposed a varying number of extracts from Beckett's text (the same extracts used in the first part), creating a sort of continuous vocal murmur. Initially, Tilbury proposed that the musicians play rapid, pianissimo phrases ("like chasing shadows"), using the same type of material as in the first part, but in a much livelier mode. Following this proposal, the musicians played for ten minutes, improvising over the audio track. Then, a notable event occurred: John Tilbury took the pianist's place, and himself played along with the track, proposing a series of highly digital phrases made up of short motifs navigating between various registers of the instrument. This led some musicians to imitate him, proposing their own motivic phrases, until Frédéric Blondy stopped the orchestra about seven minutes later. The fact that Tilbury spoke by playing rather than in words was entirely remarkable, and this episode demonstrates that Tilbury's posture remained that of an instrumentalist (whose first reflex is to demonstrate using an instrument) and free improviser (for whom music is arrived at primarily by doing, exploring, and experimenting) rather than that of an omniscient composer capable of prescribing beforehand what should be played.

31 At the end of this first phase of exploration, Tilbury seemed uncertain of the overall result. But he remained faithful to the position he expressed many times during rehearsals, letting the ONCEIM musicians find their own music within the general framework provided by Beckett's text and his own few additional instructions. Tilbury seemed not to want to guide the musicians more explicitly in their approach to this second part, and ultimately, Frédéric Blondy took over. He proposed a series of steps that were supposed to allow the musicians to better realize the sonic image Tilbury was after, asking them to first make "tenuto sounds, pianissimo, so we get used to [these] sounds with the track", then "very short, repeated sounds [...] like a drone [...], in an obsessive way, keeping the same contact between the overall sound [of the orchestra] and the [vocal] track," and then "doing the same thing again, but in such a way that just a small group plays at first, then another small group, then another, etc.," with Blondy conducting the entries and exits of these small groups, and finally, a last version, with the same idea of circulation between the different subgroups but "without conducting."

32 The two episodes we have just described call for a few general remarks. The fact that Tilbury did not really play the role of composer (or, in any case, did not follow the model of more "directive" composers that the musicians might have worked with in the past) clearly led the orchestra to operate as it would in a situation of free 
improvisation. Thus, the musicians gradually brought back the practice of "debriefing"-group discussions of varying length aimed at critically assessing a past performance, and which consisted in comparing individual judgments of a performance, identifying its problematic or notable aspects, and providing more or less explicit processes of validation (or prohibition) (see Canonne 2018).

These discussions typically involved a limited number of musicians-usually those most active in the fields of jazz and improvised music, who made up a sort of first circle with particularly strong influence within ONCEIM. Having this specific symbolic capital (accumulated within the space of improvised and experimental music) was a determining factor in a musician's propensity to take part in these discussions. Gender might also have played a role, for it was almost exclusively men who spoke during them (but, as we have seen, men are numerically dominant in the orchestra, so it is difficult to draw any definitive conclusion here). Furthermore, although we do not know the social characteristics of all the members of ONCEIM, we might also assume that the tendency to speak during these debriefings varied on the basis of a member's class or class fraction of origin. In contrast, other factors, such as instrument played, could not have had the same weight as in a traditional orchestra (see for example Lehmann 2005: 192-220)-since, as we have seen, the collective practice defended by ONCEIM tends to erase the functional contrasts between sections in favour of a shared quest for a certain timbre and an egalitarian ethics of performance. Seniority also could not have been a significant factor, since ONCEIM is only a few years old and most of its members joined at the same time.

These discussions played an important role in the collective shaping of the performance, even at the level of the individual instrumental choices. Thus, during the discussion initiated by the bass player, the trumpeter (who is part of this first circle) pointed out, almost in passing, how appropriate he found the material chosen by one of the cellists was, precisely because her choice immediately placed the orchestra at a certain level of sonic presence and allowed the musicians who next entered the piece to do so without feeling like they were "walking on eggshells." And the cellist played precisely this material (a relatively salient low G, first played pizzicato ${ }^{19}$ and then $\operatorname{arco}^{20}$ ) in all subsequent versions of the piece, through to the final concert.

The fact that Frédéric Blondy, the artistic director of ONCEIM, gradually shifted from his role as "translator" of Tilbury's remarks and comments (which included literally translating Tilbury's English instructions into French) to the role of "boss" (to quote one of the ONCEIM musicians) is even more remarkable. Indeed, as rehearsals advanced, he came to increasingly occupy his usual position of authority, discussed above: somewhere between conductor and producer ${ }^{21}$-with the dimension of expertise that goes along with that position. He did this first by giving the musicians much more detailed feedback on their musical production than Tilbury did, and then, during work on the second part of the piece, by clearly indicating a certain musical direction, a fact that several members of the orchestra did not fail to notice ${ }^{22}$.

It is interesting that the resurgence of group discussions in which Blondy's feedback and indications played a preponderant role did not entail the disappearance of the "composer-performer" organizational framework implied by the nature of the project (i.e. an orchestra commissioning a piece from a composer). In fact, certain members did not hesitate to play one model against the other when it allowed them to better argue their point during the group discussions. Thus, when one saxophonist suggested using 
more "idiomatic" material (that is, that the saxophones would sound like saxophones, the basses like basses, etc.) in order to emphasize the "path of orchestration" implied by the successive entries of various instruments during the first part, and when Blondy did not really seem to agree with this proposal, the saxophonist abandoned the "collegial" mode of discussion that had prevailed until then in order to obtain directly from the composer, if not approval, at least a more precise indication of the type of instrumental material to be used.

Similarly, Blondy's "taking charge" of the orchestra must also be understood in light of the composer-performer relationship. His action, far from appearing to compete with what the composer had proposed, took the form of an expert intervention: the contribution of a musician who, thanks to the experience he has accrued playing his instrument (here, ONCEIM, as an orchestra of improvisers), is familiar with its inner workings and thus can help the composer solve problems by proposing the solutions that will sound the best on his instrument-including by adopting a very pragmatic manner of proceeding, giving the orchestra instructions in the form of progressive exercises (rather than by describing a result to be achieved), allowing them to experiment with the textual murmur Tilbury was after.

Having said that, even if Blondy's "taking charge" was presented as a purely pragmatic intervention in the service of Tilbury's project, it nevertheless led to a reconfiguration of the compositional plan for the second part of the piece. Whereas Tilbury's proposal emphasised the motivic aspect of the musical material-clearly demonstrated by his instrumental intervention during rehearsal-the music produced by the orchestra after the exercises proposed by Blondy was quasi-minimalist, comprised of short, repeated sounds, and in this respect was faithful to what Blondy had found most successful in the orchestra's first attempts. Here, he based himself on the idea of speed and anxiety Tilbury had asked for, but took it in a different direction: something "a bit obsessive" and "nervous," whereas Tilbury had emphasized a "swift" and "risky" aspect, inspired by the marking "Schattenhaft" used by Gustav Mahler in some of his scores. Thus, Blondy encouraged the orchestra to replace the more individualised, motivic interventions imagined by Tilbury with material aimed at producing a collective texture. In other words, whether intentionally or not, Blondy's expert interventionthe intervention of someone who knows what does and does not work within the framework of ONCEIM, what is or is not possible or difficult for its thirty musicians to do spontaneously-entailed an aesthetic reconfiguration that brought the orchestra's music more in line with his own preferences. This becomes clear by comparing video extracts 2 and 3, which were taken from the beginning and end of work on the second part of Sans respectively. Thus, Tilbury's non-prescriptive posture created a "power vacuum" (in the words of several members of the orchestra), into which some musicians dove headlong in order to promote their own understandings of the piece.

This media file cannot be displayed. Please refer to the online document http:// journals.openedition.org/bssg/643

This media file cannot be displayed. Please refer to the online document http:// 
Cially, the fact that some musicians felt the need to more precisely define the field of possible actions or to establish certain elements ahead of time testifies to tensions between the indeterminate nature of the project and the context of its musical realisation. Tilbury's profession of faith in "non-interventionism" in many respects contradicted ONCEIM's very nature, which no doubt explains why some musicians welcomed Blondy's taking charge. The ensemble's large size-and the specific problems this creates in performance (the fact that each musician essentially hears only those near to him or her; the inertia specific to large groups and the fact that each individual's influence of the whole of the orchestra is extremely limited, etc.)-makes the spontaneous emergence, within the orchestral mass, of the "duos or trios" Tilbury called for on several occasions (but refused to prescribe ahead of time) very difficult ${ }^{23}$. This led one musician to propose at one point that "small group leaders" be designated, in order to effectively carry out the rapid changes in orchestration Tilbury wanted. But, above all, the orchestra's very size made the emergence of a shared consensus through musical and verbal interactions and negotiations much more complex, and the diversity of ONCEIM's members' profiles made conflicts between sometimes contradictory interpretations likely:

"In the second part, the instructions are... much vaguer than in the first part, there are even misunderstandings, that is, sometimes some musicians are still following the previous instruction or indication, and others, with all this density of information, are trying other things" (interview with Pierre-Antoine, saxophonist, 32 years old).

In this context, prescriptive statements, whether from the artistic director or an influential musician in the orchestra, can appear as a form of arbitration-an essential resource for bringing musicians into agreement when it is otherwise difficult to do so, by instituting a common musical norm to be imposed on improvisers over and above their highly diverse individual aesthetic preferences, allowing them to carry out the musical project imagined by an outside member of the orchestra in the most satisfactory way possible.

It is precisely to this diversity that we would like to turn now, by showing how the work sessions on Tilbury's project revealed the various relationships to musical performance that co-exist within ONCEIM.

\section{Confronting Indeterminacy}

Let us therefore continue to narrow the social scope of our observation. Beneath the layer of the vague interactional framework created by John Tilbury's posture, and beneath the attempts of some influential ONCEIM members (its artistic director and musicians from the "first circle") to fill the prescriptive void left by the composer, we find musicians' concrete ways of individually negotiating instructions and developing their musical material.

It is striking to note that the musicians' reception of Tilbury's posture of "nonimposition" can be distributed along a continuum with the following two extremes: on the one hand, some considered (with regret) that the composer simply had not managed to clearly formulate his compositional intentions, which were nevertheless real; at the opposite end, some musicians saw Tilbury's attitude and his encouragement of initiative-taking and spontaneous proposals as an open invitation to the ensemble to 
co-create the piece with him, and therefore regretted the more or less explicit attempts of some members to fix things in place more rigidly.

This contrast can be seen in musicians' attitudes toward the directions for the first part of Sans during rehearsals. Although, as we have seen, Tilbury's initial instructions laid out with relative clarity the contours of the collective musical action to be taken (the order in which musicians enter the piece, dynamic ranges), it was nevertheless up to each musician to develop and propose sonic material to go along with the audio track. One attitude consisted in choosing, relatively early on in the work process and through to the final performance, a small repertoire of specific instrumental materials thought to be in conformity with Tilbury's instructions. In a sense, musicians who took this attitude adopted the traditional posture of the performer who follows the sequence of musical determinations initiated by the composer, establishing the details (choice of dynamics, tempo, etc.) of his or her interpretation prior to performing publicly and on the basis of his or her reading of the piece, the intentions he or she attributes to the composer, implicit norms of expressivity, and so on. Thus, Bertrand explains:

"We have a small menu we can choose from, so we have a small range of choice, but we don't really have room to make personal musical decisions. [...] And I think that [my material] didn't really change too much [over the course of rehearsals]" (interview with Bertrand, saxophonist, 55 years old).

In contrast, several of the musicians interviewed emphasized the variability of their musical contribution in each performance of the first part, noting that the content of their contribution was explicitly tied to what each "moment" seemed to call for:

"Once the stage has been set for 30 minutes, we come in and we punctuate, we try to find a space ... [...] That's how I think of music within ONCEIM [...]: 'What can I do, when I play at a given moment, that can make it so the music stays in tension" (interview with Louis, trumpeter, 34 years old).

In line with this discursive opposition, we can distinguish two contrasting tendencies within musicians' individual strategies: some played material that remained relatively stable from the first run-through to the final performance, while others used multiple instrumental techniques and made various sonic proposals over the course of rehearsals. Here, it is instructive to look at the different entrance sequences played by ONCEIM's three bassists, since the fact that these three entered the piece near one another-in seventh, eighth, and ninth positions-and play the same instrument facilitates comparison of their musical choices. Frédéric's and Sebastien's entrance sequences were characterized by consistency: Sebastien systematically chose long, low, tenuto notes that blended into the sonic mass, while Frédéric alternated between long, low tenuto notes and a very light bowing of the strings-the only exception being a pizz with the left hand that he played immediately before playing arco during the fifth rehearsal. In contrast, Benjamin proposed almost as many different musical entrances as there were rehearsals: during the first rehearsal, he chose to rub the bow against the body of the instrument; next, he performed col legno ${ }^{24}$ movements near the bottom of the tailpiece; during the third rehearsal, he briefly used his bow near the bottom of the tailpiece and then changed his mind-he put down his bow and struck the soundboard with his fingers several times near the F-holes. During the fourth rehearsal, he opted to rub a snare drum stick against the body of the instrument; during the fifth, he alternated between sliding and lightly striking his bow against the bottom of the tailpiece; and during the sixth and final rehearsal he simply slid the bow along the strings. 
These two contrasting relations to the instructions for the piece also structured rehearsals of the second part of Sans. Tilbury's "instrumental intervention," described above, was far from univocally received by the orchestra. Some members grabbed hold of the sonic figures the composer played on the piano, considering with satisfaction that, finally, he had provided them with explicit instructions:

"After John played on the piano, we understood that he wanted 'tudududu,' like that, phrases. So after that I put the cello down more, because otherwise, basically I would have played the whole piece with the cello horizontal" (interview with Déborah, cellist, 37 years old.)

In contrast to this compliant relation to Tilbury's suggestions, Benjamin felt that while the composer's intervention on the piano effectively expressed his intentions, the type of material he suggested was not relevant at the scale of the orchestra, leading him at times to choose very different material. In doing so, he took on the role of a quasi-coauthor of the piece, considering Tilbury's indication to be no more than a proposal, rather than a veritable instruction-as one path to explore among others:

"What he played, it worked! But for us, the thirty of us to do it... And me [...] I thought about it, it influenced [...] my decisions, what is to be done, what is to be taken. And so then either I take on this brouhaha and I enter into it completely, or sometimes I want some of the voices to be heard, and it seems to me that I decided in those moments to do something not at all fast and all that, but continuous, and tenuto, that can emerge a bit, or something long, or..." (interview with Benjamin, bassist, 49 years old).

Another instruction regarding the second part that musicians could choose to follow (or not) was Frédéric Blondy's: we have seen that in the face of Tilbury's (voluntary or involuntary) hesitations and the things he left unsaid regarding this part, the artistic director proposed a principle of play where the musical material would circulate throughout the orchestra from small group to small group. Some musicians chose to scrupulously adhere to this proposal by forming small, fixed, closed playing groups:

"In the second part, I remember, [...] there was a small group of five or six [players] and we made very quick impacts, not loud at all. And we tried to begin, to play for a minute and a half or two minutes to create kinds of mini-dialogues between ourselves, because in any case we couldn't hear the others" (interview with Louis, trumpeter, 34 years old).

2 However, other musicians within the orchestra did not understand Blondy's proposal in this way. For example, Benjamin seems to have given up on trying to implement it ("the idea of playing in small ensembles, that could work, but pragmatically it was almost impossible with the brouhaha [of the audio track]"), calibrating his interventions instead on what he perceived of the orchestra's sonic mass as a whole. Similarly, Joris did not mention Blondy's instruction, and emphasized instead the difficulties created by the expanded scope of his listening and of his possible musical interventions:

"The musical choice to pile on an enormous number of recordings and to have us play piano, almost softer than the recordings, that's a frustrating choice from the point of view of the person playing! No matter what, you never hear the whole orchestra when you're playing in it, you always kind of feel like you are hearing it from a bit too subjective of a position. And then when you also add all that murmur, you feel kind of all alone, you don't know how it sounds on the outside" (interview with Joris, clarinettist, 36 years old).

In fact, we may note that musicians' different relations to the instructions given as well as the different practical solutions they adopted to play their parts within each section 
of Sans emerged from a tension between an "interpretive" understanding and an "improvisational" understanding of Tilbury's project. Indeed, it seems that the inherent ambiguity of Tilbury's proposal and even of his posture opened up a space of play (in both senses of the word) within which members of the orchestra could establish different relations to musical performance, falling somewhere between two extremes: at one extreme, the idea that creativity lives in the score and the preestablished intentions of the composer, and at the other, the idea that creativity is located in the performance and is shared between various actors (this distinction draws on Cook's [2018: 59] regarding Liza Lim's work with the Musikfabrik ensemble for her piece Tongue of the Invisible).

We might assume that, within their work interactions, musicians' choice of a type of relation to performance depends on their pasts and on the socializing experiences that have marked their trajectories. In the absence of precise data regarding musicians' social origins, we can only assume that these factors, in particular because of the relations to work they may imply, do in part explain the range of postures individuals adopt within the orchestra ${ }^{25}$. We also cannot fully demonstrate the role of gender in determining a musician's attitude towards instructions, since we were able to interview so few women. On the other hand, some of the biographical material we gathered during interviews confirms that in spite of the relative homogeneity of their cultural capital (a shared belonging to "cultivated" culture that creates shared schemes of perception, appreciation, and musical action), ONCEIM musicians came to incorporate potentially divergent habits of playing and working over the course of their years of training and professional experiences.

Thus, Benjamin's trajectory undoubtedly predisposed him to strongly favour an "improvisational" approach. This 49-year-old bass player, who benefited from strong inherited cultural capital, initially came to jazz "as a self-taught musician," and then amassed a certain amount of social capital by training with renowned jazz musicians such as Jean-François Jenny-Clarke. Himself a teacher of musical improvisation, his career as a performer has been defined by a multiplicity of projects and collaborations belonging almost exclusively to the space of improvised and experimental music.

Along the same lines, the 37-year-old cellist Déborah's strong support for Tilbury's non-prescriptive stance ("he left this space for us, to exist, to breathe," she said in her interview) can be connected to her experience in the fixed ensemble with which she has played for ten years: the group is an "ensemble without a leader, that works on a rather open-ended repertoire ${ }^{26 "}$ and which, in her own words "has influenced her tremendously."

Symmetrically, we may try to explain the fact that during rehearsals certain musicians took on roles closer to that of interpreters of a piece. Joris, a 36-year-old clarinettist, initially trained and played in the domain of classical music before branching out near the end of his studies to enter the space of improvised and experimental music. While he did mention some of his current hesitations around working in the classical context, he continues to recognize the value of his experiences in that domain, including the relationship of "humility" that a performer has to a composer or score. He also states that he appreciates his occasional opportunities, made possible by his friends, to play with traditional orchestras or chamber music groups ("I like it, it's really become something exotic for me"). And it would seem that Joris brought his taste for the role of interpreter to the context of rehearsals with Tilbury: 
"How should I put it, I kind of inherited...I guess, like I was saying, I don't think it's all bad, the humility a classical musician has when he interprets a composer's piece. And I felt like I was more in that mindset with Tilbury, that I wanted it to be his music, I wanted to feel who this guy was, what he wanted, what that could produce" (interview with Joris, clarinettist, 36 years old). attentive to Tilbury's instructions, and even regretted that the composer was not firmer in imposing his ideas on the orchestra. And yet, at first glance, his career trajectory could have pushed him closer to the improvisational pole. He studied jazz, improvisation (at the Conservatoire national supérieur de musique de Paris), and classical music (at the Conservatoire à rayonnement régional d'Aubervilliers) in parallel, but considers himself to be "more someone who comes from jazz," and over the last few years has stopped taking part in classical music, "by choice" ("it's a situation that doesn't really interest me anymore"), in order to dedicate himself more fully to practicing and teaching jazz and improvisation. And yet, later on in our interview, Sébastien spontaneously brought up the situation in which he found himself in 2013, when he composed a piece for ONCEIM and had to communicate his directions to the orchestra:

"For example, I know, I had practiced, I had prepared for what I was going to say at the first rehearsal, even just for myself, to make it clear, to make my thoughts clear. I knew what I wanted, what I didn't want, where I wanted the musicians' attention to go, what I wanted them to listen to and focus on, and so [...] I really wrote the points out for myself, I told myself 'Ok, I really know what I have to say to them,' because actually that's how it works" (interview with Sébastien, bassist, 39 years old).

Undoubtedly, his experience as a composer shaped his understanding of what it means to compose for (and lead) ONCEIM, and he clearly projected his preoccupations from that experience ("I know, really, what it's like") onto the experience of working on Sans. This explains, on the one hand, the care he took to follow the instructions for Sans, and, on the other hand, his slight frustration with Tilbury's lack of directivity ("in my opinion, the music he wants requires that").

However, the distinction between the "interpretation" pole and the "improvisation" pole within ONCEIM can be further refined. If we look closely, the foregoing analyses underline two criteria the ONCEIM musicians used to understand the work situation for Sans. The first criterion, which we may call "deontic," has to do with the status they ascribed to Tilbury's or Blondy's instructions, and oscillated between a regulative interpretation (an instruction is merely a suggestion, which serves to "launch" the collaboration between the musicians or to guide the orchestra in its sonic exploration $^{27}$ ) and a normative interpretation (an instruction is a direction that must be faithfully followed). The second criterion, which can be called "organizational," refers to the type of relationship each individual musician builds with the rest of the orchestra. This relationship may be either rigid (musical interactions must be structured by fixed principles) or fluid (musical interactions may arise without predefined constraints).

61 This distinction between deontic and organizational criteria also allows us to identify mixed postures, which combine interpretive and improvisational tendencies. Louis, a 34-year-old trumpeter, is an example of this mixed posture: his attitude during rehearsals combined a regulative view of instructions ("what John says, it's nothing 
actually!") with a relatively rigid relationship to the orchestra (he stuck fast to the small group he formed with his neighbours in the second part of the piece). The attitude of Jean, a 28-year-old clarinettist, was in a way symmetrical to Louis's, combining a clearly normative understanding of instructions (to such an extent that during our interview, questions about his "choices" of musical material or style of play seemed meaningless to him) with a fluid relationship to the orchestra (for him, the second part of the piece was an opportunity to constantly renegotiate his place within the overall sonic mass $)^{28}$.

Beyond the ideal-typical opposition between an "interpretive" and an "improvisational" understanding of the piece, the working sessions on the Sans project thus reveal the complex and subtle ways musicians have to actually approach the predetermined elements of a musical performance.

\section{Conclusion}

Analysis of the collaboration between John Tilbury and the ONCEIM orchestra has allowed us to reconstruct a unique process of creation. We have seen that all participants had to work with a high degree of uncertainty regarding the nature of the project and, therefore, regarding the distribution of roles and creative authority.

In a sense, ONCEIM can be seen as a counter-orchestra (for other examples, see Khodyakov 2007; Ramnarine 2017). Far from the model of the traditional orchestra, which depends on the relative centralisation of decision-making authority (vested in the figure of the conductor, although this model may give rise to "cascading" structures of authority, as Hyacinthe Ravet [2015] has noted), here we find a relational configuration in which hierarchical relations are less clear and in which all members are, in principle, potential collaborator-authors. This does not mean, however, that any reference to the traditional operation of a symphonic orchestra is null and void. Indeed, on the one hand, roles are distributed relatively clearly, at least at the beginning of the rehearsal process: musical prescription is up to the composer; the musicians play; and the artistic director mediates between the various project participants. On the other hand, we have seen that while no one played the role of conductor ${ }^{29}$ within ONCEIM, the position came to be filled de facto as a result of certain tense or critical situations. Thus, during rehearsals for the second part of the piece, Frédéric Blondy became increasingly interventionist and directive, objectively taking on a leadership role in order to advance the project, by drawing on his role as an expert who can apply an external perspective. Fundamentally, the resurgence of the organizational model of the symphonic orchestra here appears as a collective response to the indeterminacy of interactions and the uncertainty around the project itself. It is this very indeterminacy that allows for the fluid oscillation from one model of cooperation to the other-from the ideal of a "collective of unique individuals" ${ }^{30}$ to the more "pyramid-shaped" (Willener 1998) operation of a symphonic orchestra. 


\section{BIBLIOGRAPHY}

ADORNo Theodor W. (1976). Introduction to The Sociology of Music. English translation by E. B.

Ashton. New York, Seabury.

BECKER Howard s. (2000). “The Etiquette of Improvisation.” Mind, Culture, and Activity, 7: 171-176

and $197-200$

BLAKE Andrew (2009). "Recording practices and the role of the producer." In COOK Nicholas, CLARKE Eric, LEECH-WILKINSON Daniel, RINK John (eds.). The Cambridge Companion to Recorded Music.

Cambridge, Cambridge University Press: 36-53.

BOURDIEU Pierre (1984) [1979]. Distinction: A Social Critique of the Judgement of Taste. English translation by Richard Nice. Cambridge, Harvard University Press.

CANONNE Clément (2018). "Rehearsing Free Improvisation? An Ethnographic Study of Free Improvisers at Work.” Music Theory Online, 24(4). (Accessed on 28 February 2019.)

CORBETT John (2016). A Listener's Guide to Free Improvisation. Chicago, University of Chicago Press.

CooK Nicholas (2018). Music as creative practice. New York, Oxford University Press.

DONIN Nicolas (2018). "Domesticating Gesture: The Collaborative Creative Process of Florence Baschet's StreicherKreis for 'Augmented' String Quartet (2006-08)." In CLARKE Eric, DOFFMAN Mark (eds.). Distributed Creativity: Collaboration and Improvisation in Contemporary Music. New York, Oxford University Press: 70-87.

FAULKNER Robert R. (1973). “Orchestra Interaction: Some Features of Communication and Authority in an Artistic Organization." The Sociological Quarterly, 14(2): 147-157.

FRANÇOIS Pierre (2002). "Production, convention et pouvoir: la construction du son des orchestres de musique ancienne." Sociologie du travail, 44(1): 3-19.

HEINICH Nathalie (2005). L'Élite artiste. Excellence et singularité en régime démocratique. Paris, Gallimard.

KHODYAKOV Dmitry M. (2007). "The Complexity of Trust-Control Relationship in Creative Organizations: Insights From a Qualitative Analysis of a Conductorless Orchestra." Social Forces, 86(1): 1-22.

LEHMANN Bernard (2005) [2002]. L'Orchestre dans tous ses éclats. Ethnographie des formations symphoniques. Paris, La Découverte.

PAYNE Emily (2016). “Creativity beyond innovation: Musical performance and craft.” Musicae Scientiae, 20(3): 325-344.

PONCHIONNE Cayenna (2016). Tracking Authorship and Creativity in Orchestral Performance. PhD dissertation in Musicology. Oxford, Oxford University.

PRESSING Jeff (1984). “Cognitive Processes in Improvisation.” In CROZIER Ray W., CHAPMAN Anthony J. (eds.). Cognitive Processes in the Perception of Art, Amsterdam, Elsevier: 345-363.

RAMNARINE Tina K. (ed.) (2017). Global Perspectives on Orchestras. Collective Creativity and Social Agency. New York, Oxford University Press.

RAVET Hyacinthe (2015). L'Orchestre au travail. Interactions, négociations, coopérations. Paris, Vrin. 
SALADIN Matthieu (2014). Esthétique de l'improvisation libre. Expérimentation musicale et politique.

Dijon, Presses du Réel.

TAYLOR Charles (1989). Sources of The Self. The Making of The Modern Identity. Cambridge, Cambridge

University Press.

TILBURY John (2008). Cornelius Cardew (1936-1981). A Life Unfinished. Harlow, Matching Press.

WILLENER Alfred (1997). Les Instrumentistes d'orchestre symphonique. Variations diaboliques. Paris-

Montréal, L'Harmattan.

WILLENER Alfred (1998). La Pyramide symphonique: exécuter, créer? Une sociologie des instrumentistes

d'orchestre. Zurich, Seismo.

\section{NOTES}

1. Here we draw on the vocabulary commonly used by ONCEIM members themselves, who use the terms "free improvisation," "generative improvisation," and "improvised music" interchangeably to refer to forms of improvisation that are not explicitly attached to pre-defined musical scripts. It is not a matter of improvisation ex nihilo, but rather of performances that do not take as their starting point any referent, which Pressing (1984: 346) defines as a specific formal scheme or guiding image for a given piece, used by the improviser "to facilitate the generation and editing of improvised behaviours on an intermediate time scale."

2. The Météo Festival has been held every year in Mulhouse since the mid-1980s. Originally primarily dedicated to jazz and free jazz, it has gradually come to include free improvisation and experimental music, an evolution reflected in the Festival's name change in 2009, from "Jazz in Mulhouse" to "Météo" ("Weather"), "a reference to the unpredictable nature of the weather," as the Festival's press kit states.

3. ONCEIM's thirty-three members include seven women and twenty-six men.

4. We requested interviews with twelve musicians in order to have a representative sample reflecting ONCEIM's diversity both in terms of instrument (strings, woodwinds, brass) and in terms of individual trajectories (types of musical training and practices). Nine musicians agreed: we give the musician's first name, the instrument she plays within the orchestra and her age for each musician quoted in the following.

5. We should also specify that ONCEIM is primarily funded by public subsidies (in particular from the Ile-de-France Regional Department of Cultural Affairs) and that it only includes professional musicians, who make their living from taking part in multiple artistic projects and teaching.

6. The majority of ONCEIM's current members came together in 2011 at the moment of the project's creation by Frédéric Blondy. The following statement from one member illustrates this quest for aesthetic complementarity within ONCEIM: "The beginning of the work was a piece by Frédéric [Blondy] ... who gave us the artistic directions he wanted to work on. And in that piece there is a moment when I have to blow everything up. And obviously, if he made me part of the team, it's because I score goals, those goals. It's like, everyone has their own specific job" (interview with Arnaud, repaired record player and prepared soundboard, 44 years old).

7. In particular, he has recorded numerous works with John Cage, Morton Feldman, Cornelius Cardew, and Christian Wolff.

8. Along with Keith Rowe and Eddie Prévost he was part of the AMM ensemble, one of the major groups on the free improvisation scene (see Saladin 2014).

9. We should also note that he is the author of a biography of Cornelius Cardew (see Tilbury 2008). 
10. "I had a very favourable preconception of the guy, because of the music he makes, that he made with AMM and what he did with [John] Cage. [...] He has a good reputation in terms of being very kind...which goes well with being a leading figure of improvisation, after all" (interview with Joris, clarinettist, 36 years old).

11. "This is [my] first composition, and the last composition I will ever make. Maybe you can be grateful for that!" (John Tilbury, rehearsal on 25/08/17); "I'm not a director, I'm not a composer" (John Tilbury, rehearsal of 24/08/17).

12. "I'm happy with how it's going. I like the sound, I think that's what I had in mind. If you're not happy, that's really serious. What matters is what you think. If you don't like what you're doing, you better change it!" (John Tilbury, rehearsal on 24/08/17).

13. "You're the ones doing it, it's your music, if I'm asking something not viable or something like that, then we don't do it" (John Tilbury, rehearsal on 24/08/17).

14. "I'm not happy with that, I'm not sure in which directions to go with the text, but we'll do it, we'll get there... I'd like some feedback, anybody would like to make some positive contribution?" (John Tilbury, rehearsal on 24/08/17).

15. "I don't want to actually prescribe that, start composing... that would be a bad way of doing it" (John Tilbury, rehearsal on 24/08/17).

16. "I suggest..."; "Maybe you could...", etc.

17. "Those string players that play at the beginning ... it is beautiful but maybe it's just too selfeffacing ... I don't know, maybe it's not self-effacing enough, who knows?" (John Tilbury, rehearsal on 23/08/17).

18. "I belong here with you, really, I should be sitting there with you, the musicians" (John Tilbury, rehearsal on 24/08/17).

19. Pizzicato is a technique that consists of pinching and plucking a string with one's fingers.

20. Arco is a technique that consists of running the hair of the bow over the instrument's strings.

21. On the "relational" dimension of the producer's role, see in particular Blake (2009).

22. "He knows his orchestra really well, he felt that something was missing. And that's why we need a 'boss,' in quotes. He felt that something was squishy there, there was an empty space, and that's why he took charge of things. And that's what he does, Fred" (interview with Louis, trumpeter, 34 years old).

23. "Maybe we should try to play more chamber music, when different groups will come forward, others will stop playing, we'll have trio, quartet, eight people, maybe like that. Only I don't want to actually prescribe that, start composing ... that would be a bad way of doing it" (John Tilbury, rehearsal on 24/08/17).

24. Col legno is a technique that consists in striking the instrument's strings with the wood (rather than the hair) of the bow.

25. Bernard Lehmann (2005: 80-117) demonstrates that in classical orchestras, musicians' relationship to their work differs depending on their social background: "the inheritors" (those who come from a family of musicians) deny the difficulty of learning their instrument, while the "déclassés" (children from the upper classes) have a "saturnine-romantic" presentation of themselves and their work, and the "promoted ones" (children from the working class) adopt a heroic and sacrificial posture.

26. A repertoire consisting of works of "contemporary music" that include improvised contributions from players within a pre-established compositional framework.

27. "What he asked us to do was like to produce a sound that emanated from the sentence that had been read. But I don't even know what that means, that doesn't exist. But who cares? For me it's just an excuse to draw more attention to what had been said, and to the words that had been pronounced, in fact" (interview with Xavier, clarinettist, 55 years old). 
28. To explain the genesis of these various mixed postures, it would no doubt be necessary to do more in-depth biographical interviews and reconstruct musicians' social trajectories in greater detail.

29. For an analysis of the various modes by which a conductor influences an orchestra, see Ponchione 2016.

30. During a rehearsal before work on the Sans project had begun, one of the musicians laid out a point of view that most of his colleagues seemed to agree with: "[For ONCEIM to work well], there must be awareness that each individual is an indivisible being, and a centre of perception" (rehearsal on 13/06/16). On the emergence and durability of the logic of singularity within artistic spheres, see Heinich 2005 and Taylor 1989.

\section{ABSTRACTS}

This article examines the collaboration between ONCEIM-an orchestra made up of about thirty musicians specialised in musical improvisation - and the pianist and improviser John Tilbury, from whom ONCEIM commissioned a piece entitled Sans. This process of musical creation was remarkable in that all participants had to work with a high degree of uncertainty regarding the nature of the project and, therefore, the distribution of roles and creative authority. This uncertainty permeated all aspects of the collaborative work that led up to the first public performance of Sans. The present paper is based on an ethnographic study of all the rehearsals John Tilbury and ONCEIM held together, as well as on semi-directed interviews conducted with various orchestra members. We first illustrate the deep ambivalence of John Tilbury's attitude and preliminary instructions to the orchestra, which oscillated between two regulating approaches to musical activity. Next, we examine the various "prescriptive impulses" of some members of ONCEIM, which sought to fill the "vacuum of power" left by John Tilbury. Finally, within this largely indeterminate context of interaction, we show how musicians based their musical choices on deontic as well as organizational criteria.

Cet article analyse le travail de collaboration entre l'Orchestre des Nouvelles Créations, Expérimentations et Improvisations Musicales (ONCEIM) -un orchestre d'une trentaine de musicien'ne's spécialisée's dans l'improvisation- et le pianiste et improvisateur John Tilbury, le premier ayant passé au second la commande d'une pièce intitulée Sans. Ce processus de création musicale est singulier en ce que tou'te's les participante's doivent «composer » avec une forte incertitude quant à la nature du projet et, par-là, quant à la distribution des rôles et de l'autorité créatrice. Cette incertitude traverse toutes les dimensions du travail collectif précédant le concert et la « création » de Sans. Dans une première partie de l'article, nous mettons en évidence le fait que les indications préalables comme la posture de John Tilbury face à l'orchestre se caractérisent par une profonde ambivalence, oscillant entre deux conceptions régulatrices de l'activité musicale. Nous examinons ensuite les diverses «poussées prescriptives » de certains membres de l'ONCEIM visant à combler le « vide de pouvoir » laissé par John Tilbury. Enfin, dans ce cadre d'interaction largement indéterminé, nous montrons comment les instrumentistes opèrent leurs choix musicaux en fonction de critères tant déontiques qu'organisationnels. 


\section{AUTHORS}

\section{CLÉMENT CANONNE}

Sciences et technologies de la musique et du son (STMS)/CNRS/ Institut de recherche et coordination acoustique musique (Ircam)/Sorbonne Université

\section{ALEXANDRE ROBERT}

Institut de recherche en musicologie (Iremus) 